\title{
Perception of Financial Executives Regarding Merger of Indian Banks: A Critical Statistical Exploration
}

\author{
Dr.Sarbapriya Ray* \\ Associate Professor, Dept of Commerce, Vivekananda College, \\ Under University of Calcutta, Kolkata, India \\ Gopal Chandra Mondal \\ Research Scholar, Dept of Economics, Vidyasagar University, Paschim Medinipore, India \\ Mihir Kumar Pal \\ Professor, Dept of Economics, Vidyasagar University, Paschim Medinipore, India
}

\begin{abstract}
The article tries to identify factors affecting merger and acquisition decision in Indian banking sector as well as to find out the motives for mergers Indian banks based on executives' survey and their perception regarding merger of Indian banks. This empirical research based on executives' survey finds that new geographical area, cost advantage, size advantage, customer base ,inorganic growth, (HR) integration, shareholders' value, brand quality, financial inclusion, technological advantage, compliance with more regulations, corporate governance, risk perception, CSR, NPA are treated as the important strategic motives behind merger of Indian banks while considering those factors in order of magnitude of computed mean as our empirical result confirms having surveyed executives under our study. The ordinal logit model initiates one to infer that most of the respondents consider that corporate governance, in particular, has an important and significant impact on the merging decision of Indian banks. Other notable factors like inorganic growth(IG), Shareholders value(SV), Nonperforming assets(NPA), size advantage(SA) and financial inclusion(FI) are not so important factors in deciding merger decision of Indian banks as our ordinal regression results suggest.
\end{abstract}

Keywords: Perception analysis, merger, banks, executives.

DOI: $10.7176 /$ RJFA/10-1-08

\section{Introduction:}

In recent years, mergers and acquisitions have been the fiery issue in the banking sector. It has been wellaccepted method of increasing the size and value of firms in modem times. The motives behind mergers and acquisitions are economies of scale, increase in market share and revenues, taxation, synergy, geographical and other diversification. Many directors and senior managers will, in the present day, propose to their board that merging or acquiring another company will support the organization access to new or penetrate further into existing markets, acquire new products, technology, resources or management of talent (Jemison and Sitkin, 1986). The manager also deems that the target company can be acquired at less than its true value. If a company is assumed to be undervalued in the market, there may well be opportunities for asset stripping. No company will endeavor a takeover another unless it observes a prospect to significantly improve the return to its shareholders by better management and synergic impact of the merger.

In view of this, this research is new in case of banking sector of India with the focus on factors leading to taking decisions for merger and acquisition. These factors have been identified by the perception of the executives' survery undertaken. Different categories of the banks have been taken into consideration for purpose of conducting the study which will offer basis for the banks to decide whether to go for merger and acquisition or not.

The aim of this study is to identify factors affecting merger and acquisition decision in Indian banking sector as well as to find out the motives for mergers Indian banks based on executives' survey and their perception regarding merger of Indian banks.

\section{Methodology}

Basically, primary data collected from executives of several parts of India was used, which was collected through administration of questionnaires to acquire a precise and recent understanding of the on the impact of acquisition and Mergers in Indian banking sector. First, we have tried to present explanatory analysis of the general information from the respondents which contain demographic profile like job title, area of survey, educational qualification, work experience of the respondents etc. Second section analyses the perception of executives on merger issues and rating has been done on the basis of priority given by the respondents. Among three identified methods of conducting survey like face-to-face interview, telephonic interview and self administered question, we have adopted questionnaire method for collecting data from respondents because they 
are less costly and quicker to administer than other methods of collecting data. This empirical research is mainly Delhi based as the researcher has access over Delhi based respondents and moreover, data has been collected by sending questionnaire all over India. The final questionnaire containing 15 questions in pdf format has been distributed among nearly 160 respondents with a cover letter explaining concisely the purpose of the study and ensuring the confidentiality of the opinion given by the respondents. The duration of survey is carried on up to a period of 3-4 months commencing from March,2018. The final filled in questionnaire from respondents were received ultimately after giving several reminders over telephone, mail or sometimes communicating face-oface verbally. After scrutinizing 115 filled in questionnaire, 107 are found to be fit for use and remaining 8 questionnaire are rejected on ground of unsuitability (incomplete in nature). Likert's scoring system which consists of five categories of strongly agree (SA), agree (A), undecided (U), disagree (DA) and strongly disagree (SD) has been applied to each item of the questionnaire measuring perception of executives on merger issues. The Likert's scoring system weights have been assigned as

: for strongly agree (SA)- 5,

:for agree $(\mathrm{A})-4$,

:for undecided (U)- 3,

: for disagree (DA)- 2, and

:for strongly disagree (SD)- 1

*Complete questionnaire:

Q 1: Inorganic growth:

Growth of bank can be happened through internal (organic path) and external (inorganic path) means. Merger \& Acquisition (M\&A) can be considered as an inorganic strategy of growth. In the current environment, inorganic strategy has become a vital for achieving growth of bank. Do you agree this statement?

Q2: Corporate Governance:

Corporate Governance is a process that aims to strive for excellence in business operations through transparency, ethical way and accountability to its stakeholders, Government and others who deal with the bank. Do you believe that Merger \& Acquisition (M\&A) creates better corporate governance on merged/transferee bank?

Q3: Shareholders'value:

Consolidation through Merger \& Acquisition (M\&A) is the strategy followed by bank looking for enhanced value creation. Can Merger \& Acquisition (M\&A) strategy impact on increasing shareholders' value on merged/transferee bank?

Q4: NPA reduction:

Non-performing-Assets (NPA) is one of the big concern of the banks at the present era. It has negative impact on creating shareholders' value. Do you believe that Merger \& Acquisition (M\&A) strategy can reduce NPS in merged/transferee bank?

Q5: Size advantage:

Indian banking industry has recognized the size advantage "i.e.in term of assets" when it confronts competition with other banks and also size would be bringing down the transaction costs. Do you believe that the consolidation via merger \& acquisition (M\&A) can create the size advantage of merged/transferee bank?

Q6: Financial Inclusion:

Financial Inclusion refers to delivery of banking services to masses including privileged and disadvantaged people at an affordable terms and conditions. Can merger \& acquisition (M\&A) help to achieve the financial inclusion to achieve economic growth and development of merged bank as well as country?

Q7: CSR:

The corporate Social Responsibility (CSR) of bank contributes to the creation of Shareholders value. Do you believe that there is an empirical correlation between the adoption of societal responsibility and a bank's economics success with special reference to Merger \& Acquisition (M\&A)?

Apart from the above statements, consolidation of banks through Merger \& Acquisition (M\&A) has gained momentum because of the various other factors which impacts on creation of shareholders value. To what extent, do you agree with the following statement?

Q 8: Enhancement of customer base

Q 9: Entry into a new geographical area

Q 10: Create a cost advantage

Q 11: Acquisition of new brand quality

Q 12: Risk and market perception

Q 13: Cultural and Human Resources Integration

Q 14: Technological advantage

Q 15: Compliances with new Legislation 


\section{Analysis of results:}

Table-1 describes the distribution of the positions of the managerial executives who participated in the research and filled out the questionnaires.

Table:1: Nature of employment of respondents

\begin{tabular}{|l|l|}
\hline Nature of employment of respondents & Total no of respondents \\
\hline Banks \& Financial Institutions & 40 \\
\hline Corporate Executives & 40 \\
\hline Professionals(Corporate) & 80 \\
\hline Total & 160 \\
\hline
\end{tabular}

Source: Authors' estimation from collected primary data

The table 2 shows that about 24\% (26) of the respondents are employed in Bank \& Financial Institution, holding the position of the VP/CEO in the merging bank, while $26 \%$ are Corporate Executives and $49.5 \%$ are Professional (Corporate). Most of the executives responded in the survey belong to corporate bodies. The opinions they conceived and expressed in questionnaire are supposed to be pre-thought and well constructive.

Table:2: Job Title of Respondent executives

\begin{tabular}{|l|l|l|}
\hline Nature of employment of respondents & Total respondent & \% of total respondent \\
\hline Bank \& Financial Institution & 26 & 24.30 \\
\hline Corporate Executive & 28 & 26.17 \\
\hline Professional (Corporate) & 53 & 49.53 \\
\hline Total & 107 & 100 \\
\hline
\end{tabular}

Source: Authors' estimation from collected primary data

For attaining unbiasedness and conformity in analysis, we have categorized the respondents into four groups like Legal Professional, Finance Professional, Engineering \& Executive Manager and others.Job experience of respondents is judged by inspecting their designation written on the questionnaire by the respondents and partially it has been verified and supported by means of personal contact with them over telephone. It should be clearly mentioned to avoid any kind of ambiguity in understanding that the respondents projected their opinion with respect to transferee/ acquiring bank immediately after merger took place. Actually, legal professionals having CS and LLB degree assist internal legal restructuring process as well as external approval process and regulatory approval of industries or corporate entity by managing regulatory approval from different agencies like RBI, Competition Commission of India(CCI), SEBI, National Company Law Board Tribunal (NCLT) etc .

Respondents like engineering and executive managers with BE and MBA degree are involved in grass root level of executive management having middle and lower level managerial position. Consequently, they are most suitable persons to judge and perceive the direct impact of merger and acquisition (M\&As) in different hierarchies. Respondents like finance professionals having CA and ICWAI degree assist in valuation and in determination of SWAP ratio of corporate bodies in M\&As process.

Table:3: Educational Qualifications of respondents

\begin{tabular}{|c|c|c|c|c|c|c|c|}
\hline \multirow[b]{2}{*}{$\begin{array}{l}\text { Region of } \\
\text { survey }\end{array}$} & \multirow[b]{2}{*}{ Area of survey } & \multirow[b]{2}{*}{$\begin{array}{l}\text { No of } \\
\text { respondents }\end{array}$} & \multicolumn{4}{|c|}{ Educational Qualifications } & \multirow[b]{2}{*}{$\begin{array}{l}\text { Regi } \\
\text { on } \\
\text { wise } \\
\%\end{array}$} \\
\hline & & & $\begin{array}{l}\text { Legal } \\
\text { Professional( } \\
\text { CS\& LLB) }\end{array}$ & $\begin{array}{l}\text { Engineeri } \\
\text { ng \& } \\
\text { Executiv } \\
\mathrm{e} \\
\text { Manager } \\
\text { (BE \& } \\
\text { MBA ) }\end{array}$ & $\begin{array}{l}\quad \text { Financ } \\
\text { e } \\
\text { Professio } \\
\text { nal (CA\& } \\
\text { ICWAI) }\end{array}$ & $\begin{array}{l}\text { Others }(\mathrm{Ph} \\
. \mathrm{D}, \\
\text { Graduate } \\
\& \text { Post } \\
\text { Graduate } \\
\text { etc) }\end{array}$ & \\
\hline \multirow[t]{2}{*}{ North India } & Delhi NCR & 80 & 25 & 22 & 19 & 14 & \multirow{2}{*}{$79 \%$} \\
\hline & Ambala (HR) & 4 & 1 & 1 & 1 & 1 & \\
\hline \multirow[t]{2}{*}{ West India } & Mumbai & 11 & 5 & 3 & 2 & 1 & \multirow{2}{*}{$13 \%$} \\
\hline & Bengaluru & 4 & 0 & 1 & 3 & 0 & \\
\hline \multirow[t]{2}{*}{ South India } & Chennai & 3 & 0 & 1 & 2 & 0 & \multirow{2}{*}{$7 \%$} \\
\hline & Kochi & 4 & 0 & 0 & 3 & 1 & \\
\hline East India & Kolkata & 1 & 0 & 0 & 1 & 0 & $1 \%$ \\
\hline \multicolumn{2}{|l|}{ Total } & 107 & 31 & 28 & 31 & 17 & \\
\hline \multicolumn{3}{|c|}{$\begin{array}{l}\% \text { of different categories having educational } \\
\text { qualification }\end{array}$} & $29 \%$ & $26 \%$ & $29 \%$ & $16 \%$ & \\
\hline
\end{tabular}

Source: Authors' estimation from collected primary data

On the selection of respondents, priority has been given on the above mentioned executives or corporate professional with certain extent of working experience and knowledge of M\&As process having at least one 
professional degree like CA, CS,LLB etc rather than selecting layman or common people because these professional personalities have immense knowledge in restructuring procedure of the corporate bodies or banking entities. So, the opinion they posed and expressed in the questionnaire are pre-thought and well structured compatible with present scenario of the banking sector.

Out of 107 usable questionnaires collected from respondents scattered at several parts of India, most of the respondents resides in the northern part of India(about $79 \%$ of total respondents) where west India( $13 \%$ of respondents),south India(7\% of respondents) and east India(1\% of respondents) are far behind North Indian respondents. The survey reveals that most of the respondents are legal and financial professionals (about 58\% of total respondents).

Based on the differential experience viewed from feedback sheet, we have categorized job experience of respondents into 6 parts i.e 2-5 years, 6-10 years, 11-15 years, 16-20 years, 21-25 years, More than 25 years. In the survey, nearly $70 \%$ of the respondents are having experience of up to 15 years and remaining $30 \%$ are having working experience of more than 15 years. But prominently, we have observed that respondents having 6-10 years of Jobs Experience is the maximum in percentage.

Table 4: Job experience

\begin{tabular}{|l|l|l|}
\hline Jobs Experience & No. of respondent & Percentage \\
\hline $2-5$ years & 19 & $18 \%$ \\
\hline $6-10$ years & 40 & $37 \%$ \\
\hline $11-15$ years & 23 & $21 \%$ \\
\hline $16-20$ years & 20 & $19 \%$ \\
\hline $21-25$ years & 4 & $4 \%$ \\
\hline More than 25 years & 1 & $1 \%$ \\
\hline Total & 107 & $100 \%$ \\
\hline
\end{tabular}

Source: Authors' estimation from collected primary data

Table 5: Perception of Executives on Merger Issues

\begin{tabular}{|c|c|c|c|c|c|c|}
\hline Factors & $\begin{array}{l}\text { Very } \\
\text { important/Strongly } \\
\text { agree }(5)\end{array}$ & $\begin{array}{l}\text { Important/ } \\
\text { Agree (4) }\end{array}$ & $\begin{array}{l}\text { So- } \\
\text { so/Neutral } \\
(3) \\
\end{array}$ & $\begin{array}{l}\text { Less } \\
\text { important/disagree } \\
(2)\end{array}$ & $\begin{array}{l}\text { Not } \\
\text { important/strongly } \\
\text { disagree (1) }\end{array}$ & $\begin{array}{l}\text { Total no of } \\
\text { respondent }\end{array}$ \\
\hline $\begin{array}{l}1 \text { :inorganic } \\
\text { growth * }\end{array}$ & 26 & 67 & 6 & 8 & 0 & 107 \\
\hline $\begin{array}{lcl}\% & \text { of } & \text { total } \\
\text { respondent } & \\
\end{array}$ & $24 \%$ & $63 \%$ & $6 \%$ & $7 \%$ & $0 \%$ & $100 \%$ \\
\hline $\begin{array}{l}\text { Q2:Corporate } \\
\text { Governance* }\end{array}$ & 15 & 48 & 29 & 14 & 1 & 107 \\
\hline $\begin{array}{lll}\% & \text { of } & \text { total } \\
\text { respondent } & \\
\end{array}$ & $14 \%$ & $45 \%$ & $27 \%$ & $13 \%$ & $1 \%$ & $100 \%$ \\
\hline $\begin{array}{l}\text { Q3:Shareholders' } \\
\text { value* }\end{array}$ & 26 & 61 & 11 & 7 & 2 & 107 \\
\hline $\begin{array}{l}\% \text { of } \\
\text { respondent }\end{array}$ & $24 \%$ & $57 \%$ & $10 \%$ & $7 \%$ & $2 \%$ & $100 \%$ \\
\hline $\begin{array}{l}\text { Q4:NPA } \\
\text { reduction* }\end{array}$ & 12 & 35 & 27 & 31 & 2 & 107 \\
\hline $\begin{array}{lcl}\% & \text { of } & \text { total } \\
\text { respondent } & \\
\end{array}$ & $11 \%$ & $33 \%$ & $25 \%$ & $29 \%$ & $2 \%$ & $100 \%$ \\
\hline $\begin{array}{l}\text { Q5:Size } \\
\text { advantage* }\end{array}$ & 26 & 65 & 13 & 3 & 0 & 107 \\
\hline $\begin{array}{l}\% \text { of } \\
\text { respondent }\end{array}$ & $24 \%$ & $61 \%$ & $12 \%$ & $3 \%$ & $0 \%$ & $100 \%$ \\
\hline $\begin{array}{l}\text { Q6:Financial } \\
\text { Inclusion* }\end{array}$ & 20 & 60 & 22 & 5 & 0 & 107 \\
\hline $\begin{array}{l}\% \text { of } \\
\text { respondent* }\end{array}$ & $19 \%$ & $56 \%$ & $21 \%$ & $5 \%$ & $0 \%$ & $100 \%$ \\
\hline Q7: CSR & 11 & 37 & 37 & 22 & 0 & 107 \\
\hline $\begin{array}{l}\% \text { of total } \\
\text { respondent* }\end{array}$ & $10 \%$ & $35 \%$ & $35 \%$ & $21 \%$ & $0 \%$ & $100 \%$ \\
\hline $\begin{array}{l}\text { Q8:Customer } \\
\text { base* }\end{array}$ & 25 & 66 & 13 & 3 & 0 & 107 \\
\hline $\begin{array}{lll}\% & \text { of } & \text { total } \\
\text { respondent } & \end{array}$ & $23 \%$ & $62 \%$ & $12 \%$ & $3 \%$ & $0 \%$ & $100 \%$ \\
\hline
\end{tabular}




\begin{tabular}{|c|c|c|c|c|c|c|}
\hline Factors & $\begin{array}{l}\text { Very } \\
\text { important/Strongly } \\
\text { agree }(5)\end{array}$ & $\begin{array}{l}\text { Important/ } \\
\text { Agree (4) }\end{array}$ & $\begin{array}{l}\text { So- } \\
\text { so/Neutral } \\
(3)\end{array}$ & $\begin{array}{l}\text { Less } \\
\text { important/disagree } \\
(2)\end{array}$ & $\begin{array}{l}\text { Not } \\
\text { important/strongly } \\
\text { disagree (1) }\end{array}$ & $\begin{array}{l}\text { Total no of } \\
\text { respondent }\end{array}$ \\
\hline $\begin{array}{l}\text { Q9:New } \\
\text { geo.area* }\end{array}$ & 35 & 57 & 13 & 2 & 0 & 107 \\
\hline $\begin{array}{lcl}\% & \text { of } & \text { total } \\
\text { respondent } & \end{array}$ & $33 \%$ & $53 \%$ & $12 \%$ & $2 \%$ & $0 \%$ & $100 \%$ \\
\hline $\begin{array}{l}\text { Q10:Cost } \\
\text { advantage* }\end{array}$ & 32 & 55 & 16 & 4 & 0 & 107 \\
\hline $\begin{array}{l}\% \text { of } \\
\text { respondent }\end{array}$ & $30 \%$ & $51 \%$ & $15 \%$ & $4 \%$ & $0 \%$ & $100 \%$ \\
\hline $\begin{array}{l}\text { Q11:Brand } \\
\text { quality* }\end{array}$ & 17 & 67 & 20 & 3 & 0 & 107 \\
\hline $\begin{array}{lcl}\% & \text { of } & \text { total } \\
\text { respondent } & \\
\end{array}$ & $16 \%$ & $63 \%$ & $19 \%$ & $3 \%$ & $0 \%$ & $100 \%$ \\
\hline $\begin{array}{l}\text { Q12:Risk } \\
\text { perception* }\end{array}$ & 10 & 46 & 32 & 17 & 2 & 107 \\
\hline $\begin{array}{lll}\% & \text { of } & \text { total } \\
\text { respondent } & \\
\end{array}$ & $9 \%$ & $43 \%$ & $30 \%$ & $16 \%$ & $2 \%$ & $100 \%$ \\
\hline $\begin{array}{l}\text { Q13:(HR) } \\
\text { integration* }\end{array}$ & 30 & 51 & 18 & 8 & 0 & 107 \\
\hline $\begin{array}{lcl}\% & \text { of } & \text { total } \\
\text { respondent } & \end{array}$ & $28 \%$ & $48 \%$ & $17 \%$ & $7 \%$ & $0 \%$ & $100 \%$ \\
\hline $\begin{array}{l}\text { Q14: } \\
\text { Technological } \\
\text { advantage* }\end{array}$ & 19 & 63 & 20 & 4 & 1 & 107 \\
\hline $\begin{array}{l}\% \text { of } \\
\text { respondent }\end{array}$ & $18 \%$ & $59 \%$ & $19 \%$ & $4 \%$ & $1 \%$ & $100 \%$ \\
\hline $\begin{array}{l}\text { Q15:Compliance } \\
\text { with more } \\
\text { regulations* }\end{array}$ & 13 & 64 & 18 & 10 & 2 & 107 \\
\hline $\begin{array}{l}\% \text { of total } \\
\text { respondent }\end{array}$ & $12 \%$ & $60 \%$ & $17 \%$ & $9 \%$ & $2 \%$ & $100 \%$ \\
\hline $\begin{array}{l}\text { Combined } \\
\text { average of all } \\
\text { Factors* }\end{array}$ & 21 & 56 & 20 & 9 & 1 & 107 \\
\hline $\begin{array}{l}\% \text { of combined } \\
\text { respondent }\end{array}$ & $20 \%$ & $52 \%$ & $18 \%$ & $9 \%$ & $1 \%$ & $100 \%$ \\
\hline $\begin{array}{l}\text { Rating on } \\
\text { perception of } \\
\text { executives on the } \\
\text { basis of combined } \\
\text { average }\end{array}$ & excellent & good & $\begin{array}{l}\text { Cannot } \\
\text { say }\end{array}$ & $\mathrm{Bad}$ & Very bad & \\
\hline
\end{tabular}

Source: Authors' estimation from collected primary data

Rating on perception of executives on the basis of combined average suggests that around $72 \%$ of the respondents are in favour of merger of the said banks posing favourable opinion (either excellent- $20 \%$ or good$52 \%$ ) which indicates that factors undertaken will create positive effect on merger of banks.

Fig: 1: Diagramatic presentation of perception of executives on merger issues

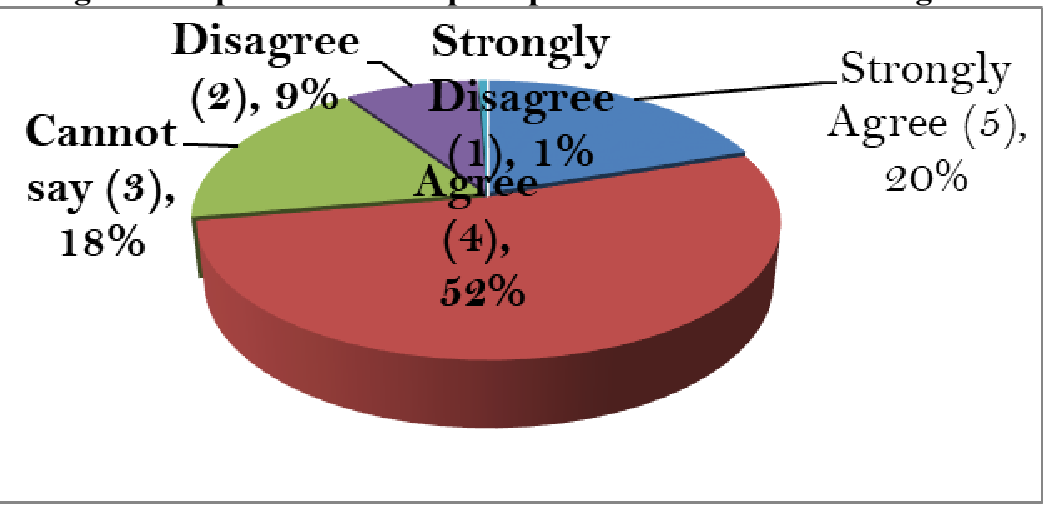

Source: Authors' estimation from collected primary data 


\section{Motivation behind mergers in Indian Banks}

The aim of this section is to present the findings on the analysis the relative importance of motives for mergers Indian banks. These findings are based on data collected from the questionnaire survey.

Table: 5: Relative Importance of Strategic Motives for merger and acquisition by Indian banks

\begin{tabular}{|l|l|l|l|}
\hline Rank & Motivation & mean & S.D \\
\hline 1 & Q:New geo.area & 4.17 & 0.85 \\
\hline 2 & Q: Cost advantage & 4.08 & 0.91 \\
\hline 3 & Q: Size advantage & 4.07 & 0.83 \\
\hline 5 & Q: Customer base & 4.06 & 0.82 \\
\hline 6 & Q: inorganic growth & 4.04 & 0.77 \\
\hline 7 & Q: (HR) integration & 3.96 & 0.93 \\
\hline 8 & Q: Shareholders' value & 3.95 & 0.94 \\
\hline 9 & Q: Brand quality & 3.92 & 0.82 \\
\hline 10 & Q: Financial Inclusion & 3.90 & 0.87 \\
\hline 11 & Q:Technological advantage & 3.89 & 0.88 \\
\hline 12 & Q:Compliance with more regulations & 3.71 & 0.95 \\
\hline 13 & Q:Corporate Governance & 3.60 & 1.01 \\
\hline 14 & Q: Risk perception & 3.42 & 1.04 \\
\hline 15 & Q: CSR & 3.35 & 1.06 \\
\hline
\end{tabular}

Source: Authors' estimation from collected primary data

Notes: $(\mathrm{N}=107)$. The mean is the average of on a scale of 1 (='no importance') to 5 (= 'very important');

It is evident from the result that exploring new geographical area for expanding banking business opportunity is ranked highest in the survey (mean: 4.17). For example, an east India based bank can explore the new opportunity in south India with a very short span of time only through M\&A process. Market power helps transferee bank to cross sell its products in the new geographical area through its acquiring existing branch networks. Merger and acquisition are used to increase market power when the bank acquires through another bank in different geographical area.

Cost advantage is the second major motive behind merger deal of the banks under our study (mean: 4.08) because the transferee bank can access the low cost of funds (such as CASA deposit through retail banking) by acquiring other bank which would help the merged entity to grow faster than other by creating good margin in terms of their advances.

Size advantage is the $3^{\text {rd }}$ major motive behind merger deal of the banks under our study (mean: 4.07) because the position of the transferee bank is upward in the market in terms of their combined assets value.

Customer base is the fourth major motive behind merger deal of banks under our study (mean: 4.06). It is so because the combined customer base of transferee/merged bank would always greater than earlier. The merged bank may be able to deliver better quality of products and services at an affordable price with greater level of satisfaction than before. The synergy effect of merged bank would increase efficiency in terms of providing service which in turn lowers the price. Therefore, it is not true that the effect of M\&A of banks on consumers would always be positive but it depends upon on other factors such as nature of Industry and market competition and other factors.

Inorganic growth is the fifth major motive after customer base behind merger deal of banks under our study (mean: 4.04). Inorganic growth arises from mergers or takeovers rather than an increase in the company's own business activity. Firms that choose to grow inorganically can gain access to new markets through successful mergers and acquisitions. Inorganic growth is considered a faster way for a company to grow compared to organic growth. Actually, inorganic growth strategies refer to external growth by takeovers, mergers and acquisitions which assume to be fast and allow immediate utilization of acquired assets. Growing banking business inorganically through M\&A process immediately expands merged entity's assets, income, market presence and stronger line of credit.

HR Integration is another major motive behind merger deal of banks under our study (mean: 3.96).It indicates that HR integration creates a big challenge for the M\&A process of our study. Post-merger HR integration has to play a strategic and critical role to achieve a successful objective of the merged bank. Previous experience shows that a main reason for M\&A failures is the inability to handle proper human resource integration. The proper dealing with the issues related to its employees and cultural integration are the tough task of HR department. The formulating strategy without considering employees concern can be a big mistake for the merged bank. For efficiently managing this part, many companies undertake feasibility study before taking any decision about what kind of people, capability and commitment the merged bank would want attain to its objective. 
Shareholder Value is one of the vital motives behind merger deal of banks under our study (mean: 3.95 ). This implies that the M\&A process can be taken as a tool to augment the wealth of the shareholders. The most the studies show that M\&A do create shareholders' value for target bank and in many cases the acquiring bank's shareholders' value tend to lose out because of their dilution of ownership and the high valuation of the target bank. In the long-run, M\&A usually lead to an increase in the share price of the merged bank. This is because the merged bank will benefit from the synergy. M\&A provide an opportunity to the acquiring bank to combine and judiciously utilize resources of both the banks on a broader scale.

Brand quality poses a crucial motive behind merger deal of banks under our study (mean: 3.92). The M\&A of bank can keep the values inherent in the brand image and the overall experience intact so that customers can still remain confident that nothing actually will change as these acquisitions often promise. So, the challenge of merged bank is to retain or maintain the superior brand after the M\&A and to ensure that customers' attitudes will remain loyal to their brand.

Financial Inclusion is another crucial motive behind merger deal of banks under our study (mean: 3.90).This signifies that financial inclusion as one of the strategy of M\&A of bank is to distribute its network in rural India to provide the basic financial services to poor and underprivileged customers. The intention is to invite large untapped depositor to park their fund in the banking system which would help to grow economy in the country. It is a win-win situation for banks and customers. With the invent of digital banking along with financial inclusion initiative undertaken by the bank, there is an opportunity to increase their household income by exploring the positive synergy M\&A process.

Technological advantage is considered to be an important motive behind merger deal of banks under our study (mean: 3.89). This is an indication of the fact that banks are now pursuing more M\&A to gain digital capabilities. This deal can help organizations acquire the necessary capabilities to bolster data management functions and deliver more accurate, consistent, timely, and secure information with minimum cost. With digital fueling new business growth, they are supplementing their organic digital growth with inorganic deals. M\&A can be a more efficient way to attain technology improvements than developing them in-house. It is likely that banks may need to allot more capital for technology infrastructure investments.

The motive as 'Compliance with more regulations' is supposed to be a significant ingredient behind merger deal of banks under our study (mean: 3.71). The interpretation lying behind the fact is that the strategies of M\&A originate from commercial aspects, its implementation needs to be carried out keeping in mind the legal framework, tax and other cost aspects, contractual obligations etc. The Indian's regulatory framework allows for several modes of carrying out M\&A transactions in India. The legal complexity of a merged bank depends upon the nature of activities, size, geographical, sectoral regulation and mode of transaction finalized. The legal framework for Mergers differs from Acquisitions in India. Mergers refer to consolidation of two or more banks in which any one or all entities lose their legal existence, whereas Acquisitions refer to the takeover of controlling stakes of one bank by another. In this situation, the legal existence of the acquired bank continues.

Corporate Governance: is believed to be a noteworthy factor behind merger deal of banks under our study (mean: 3.60). Good corporate governance, being transparent, accountable, responsive, equitable and inclusive, effective and efficient, participatory, consensus oriented, brings positive synergies. The financial performance of merged bank with higher corporate governance creates more value for the shareholders than the bank with lower corporate governance.

Risk perception is believed to be a remarkable factor behind merger deal of banks under our study (mean: 3.42). $M \& A$ is often the right choice for growth. M\&A can maximize the chances for a successful marriage while controlling the inherent risk in any business combination. The risk may be the policy risk, ethical risk, regulatory risk, labour/employment risk, operational risk, financial risk, Intellectual property risk and others. Recent deregulation allowing the development of nationwide banking has made it easier for banks to diversify their risks, but it has also made it easier for them to grow. The merged bank will take prompt action to mitigate the risk with a short span of time.

CSR (corporate social responsibility) is believed to be a notable drive behind merger deal of banks under our study (mean: 3.35). This confirms that CSR is an important aspect of strategic decision-making in M\&A strategy of banks in India. It (CSR) is more than a management buzzword. Several elements of CSR influence a Bank's propensity to pursue M\&A activity, as well as its post-transaction integration success. Banks adopt ethical behaviors and enhance economic development with the objective of improving the quality of life of its employees, the surrounding community, and society at large after the marriage to maximize the value of the stakeholders. By using social value (SV), the merged bank can increase the economic value for the stakeholders.

NPA (Non-Performing Asset) is assumed to be a distinguished drive behind merger deal of banks under our study (mean: 3.22). The amount of NPA affects not only the banking industry but the total financial system and there by the economy of the country. The consolidation of banks may be one of the options to decrease NPA in India. NPA refers to a classification for loans or advances that are in default. In most cases, debt is classified as NPA when loan payments have not been made for a period of 90 days. The merged bank now mainly focuses on 
effective management of NPAs to increase their profitability and thereby provide as much funds as possible to the industry. The merged bank should formulate an innovative ways to improve the recovery of loan or advances. Reliability statistics:

An examination had been made from the reliability of the data to check whether random Error is causing inconsistency and in turn lower reliability is at a manageable level or not, by running reliability test.

Table 6: Case Processing Summary

\begin{tabular}{|l|l|l|l|}
\hline \multicolumn{2}{|c|}{} & $\mathrm{N}$ & $\%$ \\
\hline \multirow{4}{*}{ Cases } & Valid & 107 & 100.0 \\
\cline { 2 - 4 } & Excluded $^{\mathrm{a}}$ & 0 & 0 \\
\cline { 2 - 4 } & Total $^{2}$ & 107 & 100.0 \\
\hline a. Listwise deletion based on all variables in the procedure. \\
\hline
\end{tabular}

From table 7, it is clear that the values of coefficient Alpha (Cronbach's Alpha) have been obtained; the minimum value of coefficient Alpha obtained was 0.734 .

Table 7: Reliability Statistics

Cronbach's Alpha|Cronbach's Alpha Based on Standardized Items N of Items

\begin{tabular}{|l|l|l|}
\hline .734 & .739 & 16 \\
\hline
\end{tabular}

Sources: Calculated from primary survey data using SPSS

This shows that data has satisfactory internal consistency reliability (A reliability coefficient of 0.70 or higher is considered "Acceptable" in most social science research situation.

Table 8: Correlation Matrix

\begin{tabular}{|c|c|c|c|c|c|c|c|c|c|c|c|c|c|c|c|c|}
\hline & & IG & $\mathrm{CG}$ & SV & $\mathrm{NPA}$ & SA & FI & CSR & $\mathrm{CB}$ & NGA & $\mathrm{CA}$ & BQ & RP & HRI & TA & CWR \\
\hline \multirow[t]{15}{*}{ Correlation } & IG & 1.00 & 0.352 & .496 & .314 & 466 & .323 & .285 & .367 & -.011 & .115 & .204 & .330 & -.054 & .181 & .268 \\
\hline & $\mathrm{CG}$ & .352 & 1.000 & .386 & .342 & -.345 & .397 & .450 & -.216 & -.187 & .019 & -.057 & .164 & -.049 & -.094 & .106 \\
\hline & SV & .496 & 386 & 1.000 & .316 & -.275 & .348 & .023 & -.092 & -.172 & .008 & -.045 & .118 & .017 & .086 & .029 \\
\hline & NPA & .314 & 342 & .316 & 1.000 & .358 & -.327 & 260 & -.083 & .002 & -.026 & .160 & .298 & -.051 & .137 & .134 \\
\hline & SA & .466 & -.345 & -.275 & .358 & 1.000 & .349 & .112 & .312 & .348 & .243 & .275 & -.234 & .053 & .156 & .048 \\
\hline & FI & .323 & .397 & .348 & -.327 & .349 & 1.000 & 367 & .049 & .087 & .162 & .037 & -.187 & .122 & -.022 & .022 \\
\hline & CSR & .285 & .450 & .023 & 260 & .112 & .367 & 1.000 & -.076 & .016 & .086 & .017 & .202 & .187 & -.025 & .091 \\
\hline & CB & .367 & -.216 & -.092 & -.083 & .312 & .049 & -.076 & 1.000 & .570 & .363 & .337 & -.111 & -.107 & .155 & -.020 \\
\hline & NGA & -.011 & -.187 & -.172 & .002 & .348 & .087 & .016 & .570 & 1.000 & 327 & .267 & -.017 & .090 & .243 & -.048 \\
\hline & $\mathrm{CA}$ & .115 & .019 & .008 & -.026 & .243 & .162 & .086 & .363 & .327 & 1.000 & .434 & .178 & .004 & .010 & .036 \\
\hline & $\mathrm{BQ}$ & .204 & -.057 & -.045 & .160 & .275 & .037 & .017 & .337 & .267 & .434 & 1.000 & .177 & .058 & .145 & .135 \\
\hline & $\mathrm{RP}$ & .330 & .164 & .118 & .298 & -.234 & -.187 & .202 & -.111 & -.017 & .178 & .177 & 1.000 & -.081 & .132 & .059 \\
\hline & HRI & -.054 & -.049 & 017 & -.051 & .053 & .122 & .187 & -.107 & .090 & .004 & .058 & -.081 & 1.000 & .020 & -.144 \\
\hline & TA & .181 & -.094 & .086 & .137 & .156 & -.022 & -.025 & .155 & .243 & .010 & .145 & .132 & .020 & 1.000 & .346 \\
\hline & CWR & 268 & 106 & .029 & .134 & .048 & .022 & .091 & -.020 & -.048 & .036 & .135 & .059 & -.144 & .346 & 1.000 \\
\hline \multirow[t]{15}{*}{ Sig. (1-tailed) } & $I G$ & & .000 & .063 & .000 & .050 & .046 & .001 & .042 & .455 & .119 & .017 & .000 & .291 & .031 & .003 \\
\hline & $\mathrm{CG}$ & .000 & & .089 & .000 & .022 & .001 & .000 & .013 & .027 & .423 & .278 & .046 & .309 & .168 & .140 \\
\hline & SV & .063 & .089 & & .235 & .120 & .111 & .406 & .172 & .038 & .467 & .324 & .112 & .432 & .188 & .383 \\
\hline & NPA & .000 & .000 & 235 & & .077 & .089 & .003 & .197 & .490 & 397 & .050 & .001 & .301 & .080 & .084 \\
\hline & SA & .050 & .022 & .120 & .077 & & .005 & .125 & .001 & .000 & .006 & .002 & .008 & .295 & .054 & .313 \\
\hline & FI & .046 & .001 & .111 & .089 & .005 & & .000 & .309 & .186 & .048 & .353 & .027 & .105 & .412 & .412 \\
\hline & CSR & .001 & .000 & .406 & .003 & .125 & .000 & & .219 & .434 & .189 & .432 & .018 & .027 & .401 & .176 \\
\hline & CB & .042 & .013 & .172 & .197 & .001 & .309 & .219 & & .000 & .000 & .000 & .127 & .135 & .055 & .419 \\
\hline & NGA & 455 & .027 & .038 & .490 & .000 & .186 & .434 & .000 & & .000 & .003 & .433 & .178 & .006 & 313 \\
\hline & $\mathrm{CA}$ & .119 & .423 & .467 & .397 & .006 & .048 & .189 & .000 & .000 & & .000 & .033 & .485 & .459 & .356 \\
\hline & $\mathrm{BQ}$ & .017 & .278 & .324 & .050 & .002 & .353 & .432 & .000 & .003 & .000 & & .034 & .276 & .068 & .083 \\
\hline & RP & .000 & .046 & .112 & .001 & .008 & .027 & .018 & .127 & .433 & .033 & .034 & & .203 & .087 & .274 \\
\hline & HRI & .291 & .309 & .432 & .301 & .295 & .105 & .027 & .135 & .178 & .485 & .276 & .203 & & .417 & .069 \\
\hline & TA & .031 & 168 & .188 & .080 & .054 & .412 & .401 & .055 & .006 & .459 & .068 & .087 & .417 & & .000 \\
\hline & CWR & .003 & 140 & 383 & .084 & .313 & .412 & .176 & .419 & .313 & .356 & .083 & .274 & .069 & .000 & \\
\hline \multicolumn{17}{|c|}{$=.00$} \\
\hline
\end{tabular}

\section{Source: Authors' estimation from collected primary data using SPSS}

A correlation matrix should be used in the Exploratory Factor Analysis (EFA) process displaying the relationships between individual variables. Henson and Roberts (2006) pointed out that a correlation matrix is most popular among investigators. Tabachnick and Fidell(2007) recommended inspecting the correlation matrix 
(often termed Factorability of $R$ ) for correlation coefficients over 0.30 . Hair et al. (1995) categorized these loadings using another rule of thumb as $\pm 0.30=$ minimal, $\pm 0.40=$ important, and $\pm .50=$ practically significant. If no correlations go beyond 0.30 , then the researcher should reconsider whether factor analysis is the appropriate statistical method to utilize. In other words a factorability of 0.3 indicates that the factors account for approximately $30 \%$ relationship within the data, or in a practical sense, it would indicate that a third of the variables share too much variance, and hence becomes impractical to determine if the variables are correlated with each other or the dependent variable (multicollinearity).

The table 8 shows the correlation between the dimensions of executives' perception regarding merger of Indian banks. There is positive correlation between IG and CG (0.352), IG and CG (0.496), IG and NPA (0.314), IG and SA(0.466), IG and SA(0.466), IG and FI(0.323), IG and CSR(0.285), IG and CB (0.367), IG and CA(0.115), IG and BQ (0.204), IG and RP (0.330), IG and TA (0.181), IG and CWR (0.268) and insignificant negative correlation between IG and NGA (-0.011), IG and HRI (-0.054) and so on .

\begin{tabular}{|l|l|l|}
\hline \multicolumn{3}{|c|}{ Table 9: Communalities } \\
\hline & Initial & Extraction \\
\hline IG & 1.000 & .541 \\
\hline CG & 1.000 & .709 \\
\hline SV & 1.000 & .789 \\
\hline NPA & 1.000 & .573 \\
\hline SA & 1.000 & .559 \\
\hline FI & 1.000 & .718 \\
\hline CSR & 1.000 & .666 \\
\hline CB & 1.000 & .656 \\
\hline NGA & 1.000 & .643 \\
\hline CA & 1.000 & .693 \\
\hline BQ & 1.000 & .534 \\
\hline RP & 1.000 & .736 \\
\hline HRI & 1.000 & .850 \\
\hline TA & 1.000 & .751 \\
\hline CWR & 1.000 & .638 \\
\hline Extraction Method: Principal Component Analysis. \\
\hline
\end{tabular}

Sources: Calculated from primary survey data using SPSS

Model Validity regarding perception of executives about banks' merger with Factor Analysis:

Factor analysis is the procedure which always been used by the researchers to organize, identify and minimize big items from the questionnaire to certain constructs under one dependent variable in a research. Here, factor analysis is used to construct the new factors affecting executives' perception regarding merger of Indian banks. Bartlett's test of Sphericity is based on chi-square transformation of the determinant of correlation matrix. KMO test was done to identify whether the data is suitable for factor analysis. Bartlett's test of sphericity and the Kaiser-Meyer-Olkin measure of sampling adequacy are both tests that can be used to determine the factorability of the matrix as a whole. It is an index to examine the appropriateness of factor analysis. High values between 0.5 and 1.0 indicate factor analysis is appropriate. Values below 0.5 imply that factor analysis may not be appropriate. 
Table 10: KMO and Bartlett's Test

\begin{tabular}{|c|c|c|}
\hline \multicolumn{3}{|l|}{ KMO and Bartlett's Test } \\
\hline \multicolumn{3}{|c|}{ Kaiser-Meyer-Olkin Measure of Sampling Adequacy..6? } \\
\hline \multirow[t]{3}{*}{ Bartlett's Test of Sphericity } & Approx. Chi-Square & 317.795 \\
\hline & df & 105 \\
\hline & Sig. & .000 \\
\hline
\end{tabular}

Sources: Calculated from primary survey data using SPSS

The results value of Bartlett's test of sphericity is significant $(\mathrm{p}<0.001, \mathrm{p}=0.000)$. It showed statistically significant numbers of correlations among the variables (Approx. chi-square $=317.795$, degree of freedom $=105$, significance $=.000$ ). In addition, the Kaiser-Meyer-Olkin Measure of sampling adequacy is 0.630 which is greater than 0.6 indicating a strong sampling adequacy of all the statements selected in the factor analysis. The factor analysis made is also significant since $\mathrm{p}=0.000$. It is suggested that if the Bartlett's test of sphericity is significant, and if the Kaiser-Meyer-Olkin measure is greater than 0.6, then factorability is assumed. It is observed that KMO being 0.630 indicates that there is no error in $63 \%$ of the sample and in the residual $37 \%$, there may be some sort of error. Barlett's test of puerility indicates that potency of relationship among variables is strong. It designates good idea to develop factor analysis for the data. Thus, based from the results, it is appropriate to proceed with factor analysis to examine factors that affecting executives' perception regarding merger of Indian banks.

Eigen value represents the total variance explained by each factor, percentage of the total variance attributed to each factor. One of the popular methods used is exploratory factor analysis in principle component analysis, where the total variance in the data is considered to determine the minimum number of factors that will account for maximum variance of data depicted.

Table 11: Total Variance Explained

\begin{tabular}{|c|c|c|c|c|c|}
\hline \multicolumn{2}{|c|}{ Component } & \multicolumn{4}{|c|}{ Rotation Sums of Squared Loadings } \\
\hline & & Total & Total & $\%$ of Variance & Cumulative $\%$ \\
\hline \multirow{6}{*}{ dimension } & 1 & 2.470 & 2.470 & 16.465 & 16.465 \\
\hline & 2 & 2.089 & 2.089 & 13.929 & 30.394 \\
\hline & 3 & 1.746 & 1.746 & 11.643 & 42.037 \\
\hline & 4 & 1.512 & 1.512 & 10.080 & 52.116 \\
\hline & 5 & 1.154 & 1.154 & 7.691 & 59.807 \\
\hline & 6 & 1.084 & 1.084 & 7.230 & 67.037 \\
\hline
\end{tabular}

Sources: Calculated from primary survey data using SPSS

This above table shows the actual factors that were extracted. If we look at the section labeled "Rotation Sums of Squared Loadings," it shows only those factors that met the cut-off criterion (extraction method). In this case, there were six factors with Eigen values greater than 1 . The " $\%$ of variance" column tells how much of the total variability (in all of the variables together) can be accounted for by each of these summary scales or factors. Factor 1 accounts for $16.465 \%$ of the variability in all 15 variables, and so on.

For extracting factors, Principal Component Analysis was used. Latent Root Criterion (factors with Eigen value greater than 1) was used for finalizing the number of factors. . This reveals that from the 15 items affecting executives perception regarding merger of Indian banks included in factor analysis, only 6 dimensions were extracted; therefore, 6 factors have been taken depending on Eigen values and variance explained by each factor emerged with a cumulative variance of 67 percent. This indicated that 6 dimensions explained 67 percent variance of the executives' perception regarding merger of Indian banks. Therefore, from table 11, it is clear that Eigen values of 6 factors are more than 1. It is clear from table 11 that approximate $67 \%$ of variance has been explained by 6 factors.

The 15 variables are now condensed to 6 Components or Factors donating $67 \%$ of the Total Variance, which defines that factors 1 to 6 are much closed to the required level of $67 \%$ cumulative variance. Researcher can just visualize Factors 1 to 6 which are condensed with Eigen values greater than 1.000 according to the Scree Plot.

Fig: 2:Scree Plot

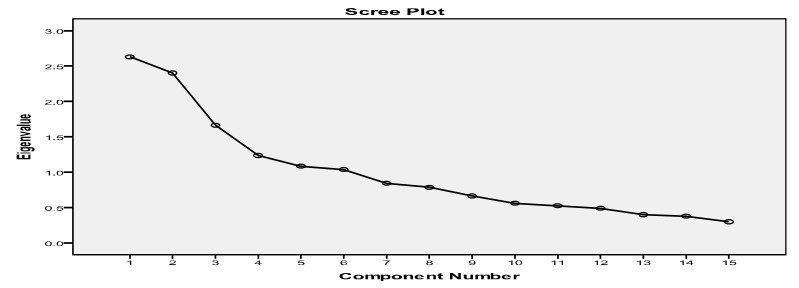

Table 12 shows the rotated factor matrix for the questionnaire. Finally, the Rotated Component Matrix 
shows us the factor loadings for each variable. We now come across each row, and highlight the factor that each variable loaded most strongly on. After performing Varimax Rotation Method with Kaiser Normalization, Factor 1 comprised of five items with factor loadings ranging from 0.524 to 0.763 . The items in Factor 1 are SA, CB, NGA, CA, BQ.Therefore, SA, CB, NGA, CA, and BQ- all subtests loaded strongly on Factor 1, which we'll call inorganic growth.

\begin{tabular}{|c|c|c|c|c|c|c|}
\hline \multicolumn{7}{|c|}{ Table 12:Rotated Component Matrix ${ }^{a}$} \\
\hline & \multicolumn{6}{|c|}{ Component } \\
\hline & 1 & 2 & 3 & 4 & 5 & 6 \\
\hline IG & .133 & .409 & .466 & .338 & -.147 & .056 \\
\hline $\mathrm{CG}$ & -.180 & .780 & .193 & -.022 & -.173 & .021 \\
\hline SV & -.092 & .042 & .067 & .127 & .050 & .869 \\
\hline NPA & -.030 & .376 & .522 & .253 & .007 & -.305 \\
\hline SA & .524 & .229 & -.372 & .244 & .083 & -.167 \\
\hline FI & .179 & .658 & -.464 & -.023 & .091 & .171 \\
\hline CSR & .022 & .764 & .141 & .010 & .245 & -.040 \\
\hline CB & .763 & -.150 & -.139 & .063 & -.133 & -.098 \\
\hline NGA & .707 & -.099 & -.077 & .111 & .218 & -.260 \\
\hline$\overline{\mathrm{CA}}$ & .742 & .133 & .141 & -.185 & -.092 & .250 \\
\hline BQ & .663 & .022 & .285 & .104 & .032 & .035 \\
\hline$\widehat{R P}$ & .065 & .066 & .839 & -.005 & .008 & .151 \\
\hline HRI & -.004 & .084 & -.040 & -.058 & .914 & .048 \\
\hline TA & .162 & -.142 & .087 & .810 & .195 & .049 \\
\hline CWR & -.023 & .137 & .029 & .732 & -.277 & .070 \\
\hline \multicolumn{7}{|c|}{$\begin{array}{l}\text { Extraction Method: Principal Component Analysis. } \\
\text { Rotation Method: Varimax with Kaiser Normalization. }\end{array}$} \\
\hline
\end{tabular}

Sources: Calculated from primary survey data using SPSS

Factor 2 comprised of three items with factor loadings ranging from 0.658 to 0.780 . The items in Factor 2 are CG, FI and CSR. Therefore,CG, FI, CSR -all loaded strongly on Factor 2, which we'll call 'corporate governance'.Factor 3 comprised of three items with factor loadings ranging from 0.466 to 0.839 . The items in Factor 3 are IG, NPA and RP. Therefore,IG, NPA, RP-all loaded strongly on Factor 3, which we'll call 'shareholders value'. Factor 4 comprised of two items with factor loadings 0.732 and 0.810 respectively. The items in Factor 4 are TA and CWR.Therefore,TA,CWR-all loaded strongly on Factor 4, which we'll call Nonperforming assets. Each of Factor 5 and Factor 6 comprised of one item. The factor loadings are 0.914 and 0.869 respectively. The item in Factor 5 is HRI and the item in Factor 6 is SV.HRI loaded strongly on Factor 5, which we'll call size advantage and SV loaded strongly on Factor 6, which we'll call financial inclusion.

Six new factors were successfully constructed using factor analysis and assigned as the factors affecting executives perception regarding merger of Indian banks. Table 13 shows the name of the new factors and percentage of variance explained for each of the factors. The first factor shows the highest percentage of variance explained when it was extracted. When the first factor, inorganic growth was extracted, then 16.465 percent of the variance would be explained and so on.

Table 13: New Factors with the Percentage of Variance

\begin{tabular}{|l|l|l|}
\hline Factor & Name & Percentage of Variance \\
\hline 1 & Inorganic growth & 16.465 \\
\hline 2 & Corporate governance & 13.929 \\
\hline 3 & Shareholders value & 11.643 \\
\hline 4 & Non-performing assets & 10.080 \\
\hline 5 & Size advantage & 7.691 \\
\hline 6 & Financial inclusion & 7.230 \\
\hline
\end{tabular}

Sources: Calculated from primary survey data using SPSS

Ordinal Logistic Regression:

Ordinal logistic regression was used because there is ordering (from low to high) in the dependent variable (quality). It models the probability of an event in comparison to all other events. The ordinal logistic regression model is known as the proportional-odds model since the odds ratio of the outcome is independent of the category $\mathrm{j}$. The odds ratio is assumed to be constant for all categories. It concurrently generates multiple equations (cumulative probability). The number of equations it estimates is one less than the number of categories in the dependent variable. Ordinal logistic regression gives only one set of coefficients for each independent variable. Thus, the coefficients for the variables in the equations do not differ significantly if they 
were estimated individually. The intercepts differ, but the slopes are fundamentally the same.

Assumptions of Ordinal Logistic Regression are :one dependent variable which means that there should be no multiple dependent variables in ordinal regression; another is Parallel lines assumption which means that there should be one regression equation for each category. Thus, the coefficients across these equations should not vary. This assumption is responsive to the number of cases. Samples with larger numbers of cases are more likely to show a statistically significant test, and indicate that the parallel regression assumption has been violated. Third assumption is that there should be adequate cell count. It is required that $80 \%$ of cells must have more than 5 counts. There should not be a zero count for any of the cells.

Before we start looking at the individual predictors in the model, we need to find out if the model gives adequate predictions. Therefore, we can examine the model fitting information in Table 14.Model-fitting information was employed to check whether there is a relationship between the model without independent variables and the model with independent variables. From Table 14, the entry labeled 'Model' indicates the parameters of the model for which the model fit is evaluated. 'Intercept only' shows a model that does not control for any predictor variables and simply fits an intercept to predict the outcome variable. The entry labeled 'Final'describes a model that involves the specified predictor variables. This was obtained through a process which maximized the log likelihood of the outcome variables. The final model shows an improvement over the 'Intercept Only'model. The entry labeled 'Chi-square' is the difference between the two -2 log-likelihood values. The observed significance level is 0.000 which is less than 0.05 . Hence, we reject the null hypothesis that the model without predictors is as good as the model with the predictors.

\section{Table 14:Model Fitting Information}

\begin{tabular}{|c|c|c|c|}
\hline Model & -2 Log Likelihood & Chi-Square & df $/$ Sig. \\
\hline $\begin{array}{l}\text { Intercept Only } \\
\text { Final }\end{array}$ & $\begin{array}{l}240.775 \\
117068\end{array}$ & 123.707 & 100 \\
\hline
\end{tabular}

Link function: Logit.

Before proceeding to examine the individual coefficients, we look at an overall test of the null hypothesis that the location coefficients for all of the variables in the model are 0 . We can base this on the change in -2 loglikelihood when the variables are added to a model that contains only the intercept. The change in likelihood function has a chi-square distribution even when there are cells with small observed and predicted counts.

The goodness-of fit test was used to check if the sample came from the population with the specified distribution. The significant chi-square statistic indicates that the model gives a significant improvement over the baseline intercept-only model. This basically tells us that the model gives better predictions than if we just guessed based on the marginal probabilities for the outcome categories. The Goodness-of-Fit is given in Table 15 which contains Pearson's chi-square statistic for the model and another chi-square statistic based on the deviance. These statistics are intended to test whether the observed data are inconsistent with the fitted model. If the significant values are large, then we would conclude that the data and the model predictions are similar and that we have a good model. The large value for significant value shows that we have a good model. On the other hand, from Table 15, we see that the observed significance level for Pearson is 0.000 and Deviance is 1.000 which is more than 0.05 ; hence the model fits the data well.

Table 15:Goodness-of-Fit

\begin{tabular}{|l|c|c|c|}
\hline & Chi-Square & Df & Sig. \\
\hline Pearson & 8302.705 & 270 & .000 \\
Deviance & 114.296 & 270 & 1.000 \\
\hline
\end{tabular}

Link function: Logit.

In the linear regression model, the coefficient of determination summarizes the proportion of variance in the dependent variable associated with the predictor (independent) variables, with larger values indicating that more of the variation is explained by the model. For regression models with a categorical dependent variable, it is not possible to compute a single statistic that has all of the characteristics of the linear regression model, so these approximations are computed instead. The following methods are used to estimate the coefficient of determination. Cox and Snell (1989) (R-Square) is based on the log likelihood for the model compared to the log likelihood for a baseline model. However, with categorical outcomes, it has a theoretical maximum value of less than 1, even for a "perfect"model. Nagelkerke (1991) (R-Square ) is an adjusted version of the Cox \& Snell that adjusts the scale of the statistic to cover the full range from 0 to 1 . McFadden (1974) (R-Square) is another version, based on the log-likelihood kernels for the intercept-only model and the full estimated model. The model with the largest statistic is "best" according to this measure. Table 16 shows these values which indicate the fitting model is good according to these measures. 


\begin{tabular}{|l|r|}
\hline \multicolumn{2}{|c|}{ Table 16:Pseudo R-Square } \\
\hline Cox and Snell & 0.685 \\
\hline Nagelkerke & 0.764 \\
\hline McFadden & 0.508 \\
\hline Link function: & \\
\hline
\end{tabular}

Link function: Logit.

Sources: Calculated from primary survey data using SPSS

This test was carried out to check if the regression coefficients are the same for all the various categories. This is a very strong assumption for the ordinal logistic regression technique since the relationship between the independent variables and the logits must be the same. Thus, they must have the same slope.

From Table 17, the row labeled 'Null' contains -2 log-likelihood value for the constrained model, the model that assumes the lines are parallel. The row labeled 'General's for the model with separate lines or planes. The entry labeled 'Chi-square' is the difference between the two -2 log-likelihood values. The p-value is 0.066 which is not less than 0.05 , so we do not reject the null hypothesis and conclude that there is no significant difference in the coefficients between the models. This is a strict agreement of the parallel line assumption since the relationship between the independent variables and the logits are the same for all the logits.For our models, the test of parallel lines can help us assess whether the assumption that the parameters are the same for all categories is reasonable. This test compares the estimated model with one set of coefficients for all categories to a model with a separate set of coefficients for each category. We see from Table 17 that the assumption is plausible for this problem where the observed significant level is large.

Table 17:Test of Parallel Lines ${ }^{\mathrm{a}}$

\begin{tabular}{|l|r|r|r|r|}
\hline Model & -2 Log Likelihood & Chi-Square & df & Sig. \\
\hline Null Hypothesis & 117.068 & & & \\
General & 97.013 & 20.055 & 12 & .066 \\
\hline
\end{tabular}

The null hypothesis states that the location parameters (slope coefficients) are the same across response categories.

a. Link function: Logit.

We also want to test the assumption that the regression coefficients are the same for all categories. If we reject the assumption of parallelism, we should consider using multinomial regression, which estimates separate coefficients for each category. Since the observed significance level in Table 17 is large, we don't have sufficient evidence to reject the parallelism hypothesis.

Table 18:Parameter Estimates

\begin{tabular}{|ll|r|r|r|r|r|r|r|}
\hline & & & & & & \multicolumn{2}{|c|}{$95 \%$ Confidence Interval } \\
\cline { 6 - 8 } & & Estimate & Std. Error & Wald & df & Sig. & Lower Bound & Upper Bound \\
\hline Threshold & {$[\mathrm{mg}=2.00]$} & 7.379 & 2.452 & 9.058 & 1 & .003 & 2.574 & 12.185 \\
& {$[\mathrm{mg}=3.00]$} & 12.278 & 2.668 & 21.175 & 1 & .000 & 7.049 & 17.508 \\
& {$[\mathrm{mg}=4.00]$} & 17.683 & 3.030 & 34.047 & 1 & .000 & 11.743 & 23.622 \\
Location & -.073 & .342 & .045 & 1 & .831 & -.743 & .597 \\
& $\mathrm{IG}$ & 3.756 & .516 & 53.071 & 1 & .000 & 2.746 & 4.767 \\
& $\mathrm{CG}$ & .071 & .269 & .069 & 1 & .793 & -.457 & .598 \\
& $\mathrm{SV}$ & .316 & .263 & 1.441 & 1 & .230 & -.200 & .831 \\
& $\mathrm{NPA}$ & .049 & .371 & .017 & 1 & .896 & -.679 & .776 \\
$\mathrm{SA}$ & -.272 & .344 & .628 & 1 & .428 & -.946 & .401 \\
\hline
\end{tabular}

Link function: Logit.

**The Wald statistic is the square of the ratio of the coefficient to its standard error.

The examination of the estimated parameters (table no. 18) reveals that the impact of corporate governance on merger of Indian banks has statistically significant importance over the merger decision. The coefficient value of corporate governance $(\mathrm{CG})$ is significantly positive, meaning that the executives who consider corporate governance $(C G)$ to be the most important factor in merging decision of different Indian banks will go on supporting frequently by casting their preference to corporate governance ; compared to the executives who consider that corporate governance $(\mathrm{CG})$ is not too important. Other notable factors like inorganic growth(IG), Shareholders value(SV), Non- performing assets(NPA), size advantage(SA) and financial inclusion(FI) are not so important factors in deciding merger decision of Indian banks as our ordinal regression results suggest.

In conclusion, following the application and validation of the ordinal logit model, it has resulted that the sixth factors are confirmed, which were supposed to have influence on merger decision of Indian banks. But, from the computed results, one can infer that most of the respondents consider that corporate governance, in particular, has an important impact on the merging decision of Indian banks. 


\section{Findings and conclusion:}

In analyzing executives' perception relating to merger issues of banks in Indian perspective, new geographical .area, cost advantage, size advantage, customer base, inorganic growth, (HR) integration, shareholders' value, brand quality, financial inclusion, technological advantage, compliance with more regulations, corporate governance, risk perception, CSR, NPA are treated as the important strategic motives behind merger of Indian banks while considering those factors in order of magnitude of computed mean as our empirical result confirms having surveyed executives under our study. Rating on perception of executives on the basis of combined average suggests that around $72 \%$ of the respondents are in favour of merger of the said banks posing favourable opinion (either excellent- $20 \%$ or good-52\%) which indicates that factors undertaken will create positive effect on merger of banks.

Having pooled opinion of several executives who pose their well- thought judgment, factor analysis suggests that there are several factors affecting the merger issues of banks in India like inorganic growth, corporate governance, shareholders value, non-performing assets, size advantage, financial inclusion etc. These factors respectively carry the highest factors loading which means these six factors are most important while executives are posing opinion regarding merger issues of banks in Indian perspective. The ordinal logit model initiates one to infer that most of the respondents consider that corporate governance, in particular, has an important and significant impact on the merging decision of Indian banks. Other notable factors like inorganic growth(IG), Shareholders value(SV), Non- performing assets(NPA), size advantage(SA) and financial inclusion(FI) are not so important factors in deciding merger decision of Indian banks as our ordinal regression results suggest.

\section{Limitations and future research direction of the Study:}

The present study has a number of limitations that should be acknowledged. The study is largely confined to a limited number of executives scattered in different parts of India, especially northern India, for a shorter period of time. The data collection was based on the opinion of the respondents and opinion of a human being may change from time to time. The data collection are primary in nature, therefore it suffers from the limitations of primary data. Some executives were reluctant in answering the questions. The sample size is very limited due to time constraint. Therefore, sample size may not be precisely practicable for the large population of the country. It is true that mergers and acquisition in banking sector is an enduring activity in the world of business where sick banks must be merged in large banks to protect the rights of consumers and hence, transferor and transferee banks create synergy, customers also get benefits of the merger. When a merger takes place one firm has to water down itself into another firm, but it is not just the transfer of assets and liabilities but the lives of respective employees are also associated with it. But, in this study, we ignore the fact of the employees who do not get satisfaction in the transferee bank, rather causing considerable trauma for employees and managers of both the acquiring and acquired banks that result in attitudinal and efficiency problems as well as turnover of valued employees.

In conclusion, this study contributes and will provide meaningful insights to academia by providing a theoretical framework to understand executives' perception regarding merger issues of banks in India as well as abroad.

\section{References}

[1] Cox, D. R., and E. J. Snell. The Analysis of Binary Data, 2nd ed. London: Chapman and Hall, 1989.

[2] Henson RK, Roberts JK(2006), Use of Exploratory Factor Analysis in Published Research: Common Errors and Some Comment on Improved Practice, Educational and Psychological Measurement, 2006;,vol.6(3).

[3] Hair J, Anderson RE, Tatham RL, Black WC. Multivariate data analysis. 4th ed. New Jersey: Prentice-Hall Inc; 1995.

[4] Jemison,D.B and Sitkin,S.B(1986), Corporate Acquisitions: A Process Perspective, The Academy of Management Review,vol. 11(1),pp:145-163.

[5] McFadden, D. Conditional logit analysis of qualitative choice behavior. In: Frontiers in Economics, P. Zarembka, eds. New York: Academic Press, 1974.

[6] Nagelkerke, N. J. D(1991), A note on the general definition of the coefficient of determination, Biometrika, vol. 78, 1991, pp. 691-692.

[7] Tabachnick BG, Fidell LS. Using Multivariate Statistics. Boston: Pearson Education Inc; 2007. 